\title{
The Long-Run Stability of Money in the Proposed East African Monetary Union
}

\author{
Simplice A. Asongu ${ }^{1+}$, Oludele E. Folarin², and Nicholas Biekpe ${ }^{3}$ \\ ${ }^{1}$ African Governance and Development Institute, Cameroon \\ ${ }^{2}$ University of Ibadan, Nigeria \\ ${ }^{3}$ University of Cape Town, South Africa
}

\begin{abstract}
This study investigates the stability of money in the proposed East African Monetary Union using annual data within 1981-2015 of five countries comprising the East African Community. A standard money demand function is designed and estimated using a bounds testing approach to cointegration and error correction modeling. Findings show that countries exhibit divergence that is articulated in terms of differences in cumulative sum (CUSUM) and CUSUM squared (CUSUMSQ) tests, short- and long-term determinants, and error correction during a shock. Based on the CUSUM and CUSUMSQ tests, results show that Burundi, Rwanda, and Tanzania have stable money demand, whereas the remaining countries, namely, Kenya and Uganda, have partial stability only. During a shock, Kenya is the fastest to restore its long-run equilibrium, followed by Tanzania and Burundi.
\end{abstract}

Keywords: Stable, demand for money, bounds test

JEL Classifications: E41, C22, O55

Received 15 January 2020, Revised 21 April 2020, Accepted 3 June 2020

\section{Introduction}

This study focuses on assessing the long-run stability of money in the proposed East African Monetary Union (EAMU) as motivated by three main scholarly and policy tendencies: (i) the policy relevance of understanding EAMU's future monetary stability, (ii) debates on monetary policy effectiveness based on the stability of money demand, and (iii) existing literature gaps. These motivations are substantiated chronologically.

First, on the policy front, the recent European Monetary Union (EMU) crisis and subsequent negative externalities have shown that monetary arrangements that are not robust to various

\footnotetext{
+Comesponding Author: Simplice A. Asongu

Lead Economist and Director, African Governance and Development Institute, P.O. Box 8413, Yaoundé, Cameroon, Email: asongus@afridev.org

Co-Author: Oludele E. Folarin

Ph.D. Candidate, Department of Economics, University of Ibadan, Ibadan, Nigeria. Email: oludelefolarin@gmail.com Co-Author: Nicholas Biekpe

Professor and Director, Development Finance Centre, Graduate School of Business, University of Cape Town, Cape Town, South Africa. Email: nicholas.biekpe@gsb.uct.ac.za
} 
macroeconomic shocks are characterized by serious disequilibria (Asongu, 2013a). Thus, understanding the future stability of money in the proposed EAMU is important.

Second, the relevance of interest rates as a monetary policy instrument to the stability of the money demand function is still open to debate (Asongu, 2016). Building on the premise that monetary policy is connected to the nature of money demand, certain literature maintains that appropriate monetary policy instruments influence money supply in stable money demand (Poole, 1970). Accordingly, interest rate can be used feasibly as an effective monetary policy instrument in stable money demand. Therefore, money supply is ineffective due to an unstable money demand and because it is assumed to be effective in stable money demand (Folarin \& Asongu, 2019).

Conversely, another literature maintains that the use of interest rates as a policy instrument by central banks of developing countries is inappropriate due to the stability of money demand (Rao \& Kumar, 2009). The authors hold that an unstable demand function can adapt the interest rate because predicting such a money demand function is not easy. This reason is because the determinants of money (such as opportunity and scale variables) may not convey substantial money demand information as opportunity variables reflect information on a forgone alternative of holding money. The money demand function can be responsive to interest rate changes because interest rate is an opportunity variable. Thus, predicting money demand becomes difficult, based on which interest rates can be leveraged as monetary policy instruments (Folarin \& Asongu, 2019).

Additionally, Weeks (2010) has established that the mainstream monetary policy is inappropriate in African countries because governments do not have the instruments with which to render monetary policy effective. According to Weeks (2010), a region such as sub-Saharan Africa lacks fundamental mechanisms to implement a monetary policy. This condition worsens when the policy pertains to (i) private credit's influence via channels such as open market operations and (ii) its impact on the private sector's borrowing rates through adjustment in interest rates at which central banks can lend to commercial banks. Monetary policies' inappropriateness is seen from the perspectives of traditional and alternative arrangements of discretionary monetary policy that are conducive to price stability and economic growth. It is noteworthy that monetary authorities can use policy instruments in the perspective of discretionary policy to offset adverse shocks to output by achieving either (i) a contractionary monetary policy (i.e., when economic output is above its potential) or (ii) an expansionary monetary policy (i.e., when output is below its potential). This narrative is consistent with the literature on using inflation targeting for countercyclical monetary policy (Ghironi \& Rebucci, 2000; Mishkin, 2002; Cavoli \& Rajan, 2008; Cristadoro \& Veronese, 2011; Levine, 2012; Asongu, 2014a).

Third, although the literature on the stability of money demands in developing countries is evolving (Folarin \& Asongu, 2019), it does not cover the proposed EAMU. According to 
certain scholarly perspectives, financial innovation is indispensable due to financial globalization (Asongu, 2015; Batuo \& Asongu, 2015) and thus has increased the instability of developing countries' money demand. Studies supporting this position include: Ndirangu and Nyamongo (2015) for Kenya, Kumar (2011) for 20 developing countries, and Nachega (2001) for Uganda. Section 2 below discussed that the literature on EAMU's potential has fundamentally focused on assessing the feasibility of the embryonic monetary zone. These studies hold that the potential monetary zone is not feasible in the short run. This inference is based on investigating heterogeneous empirical analyses of variables employed to assess fiscal, real, and monetary convergence (Drummond et al., 2015a, 2015b; Asongu, 2014b, 2014c; Lepetit et al., 2014; Mafusire \& Brixiova, 2013; Davoodi et al., 2013; Rusuhuzwa \& Masson, 2012; Buigut, 2011). The dominant view from the results is a selection framework of monetary integration that entails the direct disqualification of certain nations or identification of clusters. For example, in the old and new East African Community (EAC) samples, Rwanda and Burundi (see Bangaké, 2008; Mkenda, 2001) and Rwanda (see Lepetit et al., 2014; Sheikh et al., 2011) are excluded, respectively. Moreover, Drummond et al. (2015b) posit that Rwanda should be excluded from the currency union because of the absence of a robust mechanism to absorb asymmetry shocks.

This study extends the extant literature (articulated in the third strand) by contributing to the debate on monetary policy effectiveness (discussed in the second strand). By doing so, we provide insights into the relevance of monetary policy stability to the proposed EAMU (engaged in the first strand). The present study employs Pesaran et al.'s (2001) autoregressive distributed lag (ARDL) bounds test approach to cointegration. The procedure is used to assess whether is a long-run nexus exists between a monetary aggregate (i.e., M2) and its corresponding determinants. The findings on the stability of money show divergence across countries. The closest studies to the current paper are Asongu et al. (2019a) and Asongu et al. (2019b) who have focused on the proposed West African and Southern African monetary unions, respectively. The present study departs from extant money demand studies, particularly on the effectiveness of monetary policy despite unstable money demand (Kuman et al., 2013; Bahmani-Oskooee \& Rehman, 2005) and country-level money demand stability analyses (Halicioglu \& Ugur, 2005; Oskooee \& Gelan, 2009; Drama \& Yao, 2010).

The rest of the paper is structured as follows. Section 2 discusses the literature review, and Section 3 covers data and methodology issues. Section 4 presents the empirical results. Lastly, Section 5 concludes with implications and future research directions.

\section{Literature Review}

Consistent with Asongu et al. (2017), this narrative must begin by briefly highlighting the 
African Union's (AU) history and its corresponding embryonic regional monetary zones. Accordingly, the African Economic Community (AEC) or Abuja Treaty (signed on June 3, 1991) summarizes the AU's fundamental principle. The treaty requested the creation of the African Central Bank by 2018, contingent on the AEC's creation. Consequently, the African Monetary Union is broadly defined within the scope of an economic and monetary union to be managed by the proposed African Central Bank for AU states' interest. Africa's currency area creation is not an event but a process that entails the amalgamation of potential regional monetary unions, inter alia, the proposed Southern African Monetary Union, West African Monetary Union, and EAMU. Below, we discuss the existing literature on embryonic EAMU.

The EAC was founded in 1999 through a treaty signed by Kenya, Tanzania, and Uganda. This treaty embodied a monetary union creation and, subsequently, a political union between the member states for monetary and political harmonization; Burundi and Rwanda integrated the community subsequently. A customs union founded in 2005 promotes the common monetary zone creation. The currency union to be adopted in 2012 has been postponed (Miles, 2015).

In 2013, the EAC's member states entered into a protocol defining the convergence process and criteria imperative for a single currency area in the EAC (Drummond et al., 2015a, 2015b). The protocol articulated additional steps to consolidate regional integration after the ratification of two past protocols: the customs union in 2005 and common market in 2010. This situation suggests that a common currency area should be established by 2024. Although various rewards are linked to the underlying economic integration and currency union, harmonizing individual nations' currencies have certain significant challenges.

Consistent with Asongu et al. (2017), an over-ambitious monetary policy convergence criterion is established, though the implementation of customs union and common market protocols is incomplete. Asongu et al. (2017) hold that empirical studies on the embryonic EAMU can be summarized through Hegelian dialectics, namely, (i) studies supporting the feasibility of the proposed monetary union (Bangaké, 2008; Mkenda, 2001; Asongu, 2013b); (ii) studies opposing the monetary union (Rusuhuzwa \& Masson, 2012; Buigut, 2011; Mafusire \& Brixiova, 2013; Davoodi et al., 2013; Asongu, 2014b, 2014c; Lepetit et al., 2014); and (iii) studies supporting the currency union, contingent on member states' considerable policy harmonizing efforts (Sheikh et al., 2011; Kishor \& Ssozi, 2011; Falagiarda, 2010; Buigui \& Valev, 2005). To simplify, additional insights into extant empirical studies (distinct in terms of periodicity, authors, methodology, and sampled countries) in Table 1 are available in Asongu et al. (2017). 
Table 1. Empirical Studies on the Proposed East African Monetary Union (EAMU)

\begin{tabular}{|c|c|c|c|c|c|}
\hline Author(s) & Period & Countries & Methodology & Feasibility & $\begin{array}{l}\text { Justification/ } \\
\text { recommendation }\end{array}$ \\
\hline $\begin{array}{l}\text { Mkenda } \\
\text { (2001) }\end{array}$ & 1980-1998 & $\begin{array}{l}\text { Kenya, Tanzania, } \\
\text { Uganda }\end{array}$ & $\begin{array}{l}\text { Generalized Purchasing } \\
\text { Power Parity (GPPP) } \\
\text { model. }\end{array}$ & Yes & $\begin{array}{l}\text { Cointegrated real exchange } \\
\text { rates between member } \\
\text { states. }\end{array}$ \\
\hline \multirow{2}{*}{$\begin{array}{l}\text { Buigut \& } \\
\text { Valev } \\
(2005)\end{array}$} & \multirow[t]{2}{*}{$1970-2001$} & \multirow{2}{*}{$\begin{array}{l}\text { Kenya, Tanzania, } \\
\text { Uganda, Burundi, } \\
\text { Rwanda (EAC) }\end{array}$} & \multirow[t]{2}{*}{$\begin{array}{l}\text { Structural vector } \\
\text { autoregressive analysis. }\end{array}$} & No & $\begin{array}{l}\text { Asymmetric demand and } \\
\text { supply shocks. }\end{array}$ \\
\hline & & & & $\begin{array}{l}\text { Yes, with more } \\
\text { integration }\end{array}$ & $\begin{array}{l}\text { Similar speed and magnitude } \\
\text { in adjustment of shocks. }\end{array}$ \\
\hline $\begin{array}{l}\text { Bangaké } \\
(2008)\end{array}$ & $1990-2003$ & $\begin{array}{l}21 \text { African } \\
\text { countries }\end{array}$ & $\begin{array}{l}\text { System of simultaneous } \\
\text { equations and GMM. }\end{array}$ & Yes & $\begin{array}{l}\text { Yes for Kenya, Tanzania, } \\
\text { Uganda (structural } \\
\text { similarities). }\end{array}$ \\
\hline $\begin{array}{l}\text { Buigut \& } \\
\text { Valev } \\
(2009)\end{array}$ & $1990-2004$ & EAC & $\begin{array}{l}\text { Simulation of welfare } \\
\text { effects from a monetary } \\
\text { union. }\end{array}$ & Not definite & $\begin{array}{l}\text { Mutual restraint in } \\
\text { monetary policy is a } \\
\text { potential benefit. }\end{array}$ \\
\hline $\begin{array}{l}\text { Falagiarda } \\
(2010)\end{array}$ & $1990-2006$ & EAC & Cointegration analysis. & Yes/No & $\begin{array}{l}\text { Single currency viable but } \\
\text { currently doubtful. }\end{array}$ \\
\hline $\begin{array}{l}\text { Buigut } \\
(2011)\end{array}$ & $1997-2008$ & EAC & $\begin{array}{l}\text { Cointegration techniques } \\
\text { on exchange rates and } \\
\text { monetary base. }\end{array}$ & No & Only partial convergence. \\
\hline $\begin{array}{l}\text { Kishor \& } \\
\text { Ssozi } \\
(2011)\end{array}$ & $1970-2007$ & EAC & $\begin{array}{l}\text { Unobserved component } \\
\text { model and time-varying } \\
\text { parameter model. }\end{array}$ & Yes/No & $\begin{array}{l}\text { Increased but weak business } \\
\text { cycle synchronization since } \\
2000 \text {. }\end{array}$ \\
\hline $\begin{array}{l}\text { Sheikh et al. } \\
\text { (2011) }\end{array}$ & $1980-2010$ & EAC & $\begin{array}{l}\text { Cross country correlation } \\
\text { and variance analysis. }\end{array}$ & Yes/No & $\begin{array}{l}\text { Similar business patterns, } \\
\text { but for Rwanda. }\end{array}$ \\
\hline $\begin{array}{l}\text { Rusuhuzwa \& } \\
\text { Masson } \\
(2012)\end{array}$ & $1990-2010$ & EAC & $\begin{array}{l}\text { Correlation and } \\
\text { cointegration of business } \\
\text { cycle and shocks. }\end{array}$ & No & $\begin{array}{l}\text { Substantial asymmetric } \\
\text { shocks and production } \\
\text { structures. }\end{array}$ \\
\hline $\begin{array}{l}\text { Davoodi et al. } \\
\text { (2013) }\end{array}$ & $2000-2010$ & EAC & $\begin{array}{l}\text { Structural vector } \\
\text { auto-regression analysis } \\
\text { (SVAR). }\end{array}$ & No & $\begin{array}{l}\text { Weak Monetary Policy } \\
\text { Transmission Mechanism. }\end{array}$ \\
\hline $\begin{array}{l}\text { Asongu } \\
(2013 b)\end{array}$ & $1980-2010$ & EAC & Granger causality. & Yes & $\begin{array}{l}\text { Traditional monetary policy } \\
\text { instruments. }\end{array}$ \\
\hline $\begin{array}{l}\text { Mafusire \& } \\
\text { Brixiova } \\
(2013)\end{array}$ & $1980-2009$ & EAC & SVAR. & No & $\begin{array}{l}\text { Lack of macroeconomic } \\
\text { convergence. }\end{array}$ \\
\hline $\begin{array}{l}\text { Lepetit et al. } \\
\text { (2014) }\end{array}$ & 2003-2010 & EAC & $\begin{array}{l}\text { Stylized model of } \\
\text { policymakers' decision } \\
\text { problem. }\end{array}$ & No & $\begin{array}{l}\text { Uncertainty does not allow } \\
\text { for monetary and financial } \\
\text { stability. }\end{array}$ \\
\hline $\begin{array}{l}\text { Asongu } \\
(2014 b)\end{array}$ & 1981-2009 & EAC & GMM & No & $\begin{array}{l}\text { Lack of real, monetary and } \\
\text { fiscal policy convergence. }\end{array}$ \\
\hline $\begin{array}{l}\text { Asongu } \\
(2014 c)\end{array}$ & $1980-2010$ & EAC & VAR & No & $\begin{array}{l}\text { Ineffective } \\
\text { Monetary policies. }\end{array}$ \\
\hline
\end{tabular}

(Note) VAR: Vector autoregressions. GMM: Generalized Method of Moments.

(Source) Asongu et al. (2017) 


\section{Data and Methodology}

\section{A. Data}

This study uses annual data within 1981-2015 of the five countries comprising the EAC: Rwanda, Burundi, Tanzania, Kenya, and Uganda. The data are collected from the World Development Indicators (WDI) and the International Financial Statistics (IFS). The variables used are consistent with the recent literature (Folarin \& Asongu, 2019) and include real broad money (M2), real gross domestic product (GDP), real effective exchange rate, foreign exchange rate, and inflation rate. Table 2 lists the complete variable definitions and corresponding sources.

(i) Real GDP equals GDP divided by GDP deflator and is the monetary value that corresponds to a country's produced commodities over a period and evaluated at a constant price. Accordingly, real GDP is used to appreciate real income.

(ii) Real broad money equals nominal broad money divided by the GDP deflator and denotes narrow money plus savings and time deposits with commercial banks evaluated at a constant price. Real broad money and real GDP are obtained by dividing broad money and GDP, respectively, by the consumer price index.

(iii) Inflation rate is the GDP deflator and is defined as the percentage change in the consumer price level.

(iv) Exchange rate is the official exchange rate in local currency units relative to the US dollar.

(v) Foreign interest rate is a three month treasury bill, which is a short-term interest charged on government security. The first-four and fifth variables are collected from WDI, and IFS, respectively.

Table 2. Data Definitions and Sources

\begin{tabular}{|c|c|c|c|}
\hline Variables & Full names & Definitions & Sources \\
\hline RM2 & Real broad money & $\begin{array}{l}\text { Nominal broad money divided by } \\
\text { GDP deflator }\end{array}$ & World Development Indicators (WDI) \\
\hline RM1 & Real narrow money & $\begin{array}{l}\text { Nominal narrow money divided by } \\
\text { GDP }\end{array}$ & $\begin{array}{l}\text { World Development Indicators (WDI) } \\
\text { and International Financial Statistics } \\
\text { (IFS) }\end{array}$ \\
\hline RGDP & Real GDP & $\begin{array}{l}\text { Gross domestic product divided by } \\
\text { GDP deflator }\end{array}$ & World Development Indicators (WDI) \\
\hline INFL & Inflation rate & GDP deflator (Annual \%) & World Development Indicators (WDI) \\
\hline $\mathrm{EXCH}$ & Exchange rate & $\begin{array}{l}\text { Official exchange rate - local currency } \\
\text { units relative to the U.S. dollar }\end{array}$ & World Development Indicators (WDI) \\
\hline UKINTEREST & Foreign interest rate & Three month treasury bill rate & International Financial Statistics (IFS) \\
\hline
\end{tabular}

(Notes) The data used for the study span between 1981 and 2015. RM2: real broad money; real GDP: real gross domestic product; INFL: inflation rate; EXCH: exchange rate; and UKINTEREST: foreign interest rate. 
Table 3 presents the summary statistics and shows that the variables substantially vary. Thus, we are confident that reasonable estimated linkages would emerge in the assessment of the stability of money demand in the proposed EAMU.

Table 3. Descriptive Statistics of East African Community (EAC)

\begin{tabular}{|c|c|c|c|c|c|c|c|}
\hline & & RM1'Billion & RM2'Billion & RGDP'Billion & INFL & EXCH & UKINTEREST \\
\hline \multirow[t]{4}{*}{ Burundi } & Mean & 1.93 & 2.54 & 12.7 & 10.49 & 654.40 & 6.36 \\
\hline & Max & 3.18 & 4.15 & 17.9 & 38.94 & 1571.90 & 14.64 \\
\hline & Min & 1.12 & 1.27 & 9.50 & -6.06 & 90.00 & 0.30 \\
\hline & Std dv & 0.61 & 0.86 & 2.22 & 9.15 & 526.01 & 4.26 \\
\hline \multirow[t]{4}{*}{ Kenya } & Mean & 3.73 & 7.95 & 21.7 & 10.69 & 54.42 & 6.36 \\
\hline & Max & 8.32 & 17.0 & 40.6 & 41.99 & 98.18 & 14.64 \\
\hline & Min & 1.65 & 3.41 & 11.8 & 0.93 & 9.05 & 0.30 \\
\hline & Std dv & 2.07 & 3.79 & 7.95 & 7.68 & 28.58 & 4.26 \\
\hline \multirow[t]{4}{*}{ Rwanda } & Mean & 2.09 & 4.28 & 25.5 & 8.28 & 342.51 & 6.36 \\
\hline & Max & 4.20 & 12.8 & 59.5 & 51.27 & 720.98 & 14.64 \\
\hline & Min & 1.37 & 1.98 & 8.81 & -7.02 & 76.45 & 0.30 \\
\hline & Std dv & 0.77 & 2.77 & 13.1 & 10.48 & 1.41 & 4.26 \\
\hline \multirow[t]{4}{*}{ Tanzania } & Mean & 26.1 & 42.0 & 194 & 14.15 & 739.57 & 6.36 \\
\hline & Max & 62.3 & 107 & 441 & 31.17 & 1991.39 & 14.64 \\
\hline & Min & 12.6 & 10.0 & 81.8 & 4.60 & 8.28 & 0.30 \\
\hline & Std dv & 14.6 & 27.2 & 103 & 8.16 & 589.07 & 4.26 \\
\hline \multirow[t]{4}{*}{ Uganda } & Mean & 26.2 & 40.4 & 226 & 36.12 & 1267.26 & 6.36 \\
\hline & Max & 67.9 & 115 & 533 & 189.98 & 3240.65 & 14.64 \\
\hline & Min & 5.48 & 5.56 & 81.4 & -5.32 & 0.50 & 0.30 \\
\hline & Std dv & 20.9 & 34.9 & 143 & 51.75 & 926.29 & 4.26 \\
\hline
\end{tabular}

(Notes) RM2 is real broad money; RGDP is real gross domestic product; INFL is inflation rate based on GDP deflator; $\mathrm{EXCH}$ is exchange rate; UKINTEREST is UK interest rate.

\section{B. Methodology}

The Hossain (1993, pp. 91) approach is adopted for this study. This approach is consistent with the recent literature (Bahmani-Oskooee \& Gelan, 2009) on the theoretical underpinnings motivating an empirical assessment of the stability of money demand. Hence, real income is used as the scale variable, whereas opportunity variables include inflation and interest rates. In accordance with Bahmani-Oskooee and Gelan (2009), the use of interest rate as an opportunity variable in Africa could mislead policy because the region's financial sector is not well-developed. The authors have argued that nations that are characterized by less-developed financial sectors are also characterized by an interest rate that is unlikely to reflect full market conditions. Thus, the authors have recommended the use of inflation rate to address this gap. 
The extant literature has exclusively controlled for interest rates (Anoruo, 2002; Akinlo, 2006) and inflation and interest rates (Kumar et al., 2013). In this study, we control for both.

The money demand literature has also articulated the relevance of considering foreign interest rates and currency substitution in assessing the money demand function (Folarin \& Asongu, 2019). For instance, Chaisrisawatsuk et al. (2004) emphasized that the underlying investment's anticipated return should influence money demand based on citizens' consideration of foreign bonds as an alternative investment channel. It is noteworthy that currency substitution reflects exchange rate impact on money demand, whereas capital mobility impact captures foreign interest rate relevant to money demand.

Accordingly, money demand in this study is expressed as follows:

$$
M / P=f\left(y, o p, R^{f}, E\right)
$$

where $M / P$ is the real monetary aggregate, $M$ is the nominal monetary aggregate, $p$ is the price level, $y$ is the income variable, $o p$ is the opportunity variables in terms of domestic interest rate $\left(R^{d}\right)$ and inflation (INF), $R^{f}$ is the foreign interest rate, and $E$ is the real effective exchange rate.

Equation (1) can be re-expressed in a double log form as follows:

$$
\ln (M / p)_{t}=\beta_{0}+\beta_{1} \ln y_{t}+\beta_{2} R_{t}^{d}+\beta_{3} I N F_{t}+\beta_{4} R_{t}^{f}+\beta_{5} \ln E_{t}+\varepsilon_{t}
$$

where, $\ln$ is natural logarithm, $y$ is the real income, $R^{d}$ is the domestic interest rate, INF is the inflation rate, $\beta \mathrm{s}$ are the coefficients on the study variables, $\varepsilon$ is the residual term, and $t$ is the time.

Given that the variables in Equation (2) are in a time series, testing their corresponding stationary properties is relevant to avoiding spurious regressions. Stationarity properties are tested using the Phillips-Perron test because it is more reliable and efficient (compared with the Augmented Dickey Fuller test) in a time series with longer periodicity (Asongu, 2014d).

Table 4 above reports the unit root tests results, indicating that the variables are stationary at levels and first difference. This fading implies the appropriateness of the ARDL approach. Hence, Pesaran et al.'s (2001) ARDL bounds test is used to examine whether the variables are cointegrated or have a long-term relationship. Compared with other estimation procedures (e.g., Johansen and Engle \& Granger tests), the ARDL does not require variables to display the same order of integration. Equation (3) specifies the corresponding ARDL model as follows:

$$
\begin{aligned}
\Delta \ln (M / p)_{t}= & \delta_{0}+\delta_{1} \ln (M / p)_{t-1}+\delta_{2} \ln y_{t-1}+\delta_{3} R_{t-1}^{d}+\delta_{4} I N F_{t-1}+\delta_{5} R_{t-1}^{f}+\delta_{6} \ln E_{t-1} \\
& +\delta_{7} \operatorname{Trend}+\sum_{j=1}^{l} \tau_{1 j} \Delta \ln (M / p)_{t-j}+\sum_{j=0}^{m} \tau_{2 j} \Delta \ln y_{t-1}+\sum_{j=0}^{n} \tau_{3 j} \Delta R_{t-1}^{d} \\
& +\sum_{j=0}^{n} \tau_{4 j} \Delta I N F_{t-1}+\sum_{j=0}^{o} \tau_{5 j} \Delta R_{t-1}^{f}+\sum_{j=0}^{p} \tau_{6 j} \Delta \ln E_{t-1} \varepsilon_{t}
\end{aligned}
$$


Table 4. Unit Root Tests

\begin{tabular}{|c|c|c|c|c|c|}
\hline & Burundi & Kenya & Rwanda & Tanzania & Uganda \\
\hline LRM1 & -2.295 & -1.955 & -1.282 & -2.468 & -2.696 \\
\hline$\triangle \mathrm{LRM} 1$ & $-6.619 * * *$ & $-5.750 * * *$ & $-5.954 * * *$ & $-3.186 * *$ & $-5.998 * * *$ \\
\hline LRM2 & -2.674 & -2.358 & -0.479 & -2.117 & -2.433 \\
\hline$\triangle \mathrm{LRM} 2$ & $-7.783 * * *$ & $-6.954 * * *$ & $-4.433 * * *$ & $-3.600 * *$ & $-6.061 * * *$ \\
\hline LRGDP & -1.507 & -0.725 & -1.405 & -0.247 & $-3.598 * *$ \\
\hline$\triangle \mathrm{LRGDP}$ & $-3.456 * *$ & $-3.301 * *$ & $-5.986^{* * *}$ & $-3.576^{* *}$ & \\
\hline INFL & $-4.671 * * *$ & $-4.540 * * *$ & $-4.065 * *$ & -2.514 & -2.218 \\
\hline$\triangle \mathrm{INFL}$ & & & & $-7.280 * * *$ & $-5.199 * * *$ \\
\hline LEXCH & -1.118 & -1.460 & -1.604 & -1.251 & -2.404 \\
\hline$\triangle \mathrm{LEXH}$ & $-3.618^{* *}$ & $-4.747 * * *$ & $-4.796^{* * *}$ & $-3.329 *$ & $-3.409 * *$ \\
\hline UKINTEREST & -2.495 & -2.495 & -2.495 & -2.495 & -2.495 \\
\hline$\triangle$ UKINTEREST & $-6.320 * * *$ & $-6.320 * * *$ & $-6.320 * * *$ & $-6.320 * * *$ & $-6.320 * * *$ \\
\hline
\end{tabular}

(Notes) *,**, and ${ }^{* * *}$ are significance levels of $10 \%, 5 \%$, and $1 \%$ respectively. RM1 is the real narrow money; RM2 is the real broad money; RGDP is the real GDP; INFL is the inflation rate based on the GDP deflator; EXCH is the exchange rate; and UKINTEREST is the UK interest rate. The reported values are the corresponding t-statistics.

Under the ARDL technique, Equation (3) is estimated to perform the bunds test. The Schwarz information criterion (SIC) is used to determine the optimal lag used for each variable. Other approaches to determining the optimal lag are available, such as the Akaike information criterion, Hannan-Quinn criterion, and adjusted R-squared. Nevertheless, our choice of SIC is due to the need to perform the regression analysis using the most parsimonious lag structure given the study's small sample size. The Fisher (F)-statistics is then estimated using the Wald restriction by assigning restrictions to the lag value of all level series in the two underlying equations (see Pesaran et al., 2001). The corresponding estimated F-statistics is used to assess the evidence of a long-term nexus between the study variables. The null hypothesis related to the Wald restriction imposed on Equation (3) is $\delta_{2}=\delta_{3}=\delta_{4}=\delta_{4}=\delta_{5}=\delta_{6}=0$ The relationship reflects the presence of a long-term nexus.

The value of F-statistics is obtained by comparing the critical values at the lower and upper limits provided by Pesaran et al. (2001). With regard to the cointegration test, if the estimated F-statistics is higher than the critical value of the upper limit, then the null hypothesis of no cointegration is rejected, and the presence of a long-term relationship is established. Conversely, if the estimated F-statistics falls below the lower critical value, then the hypothesis of a long-term nexus is not valid. Similarly, evidence of a long-term relationship is inconclusive if the F-statistics falls between the lower and upper critical values. Table 5 shows the cointegration test findings, indicating that cointegration is evident in four out of the five selected EAC countries, namely, Burundi, Kenya, Tanzania, and Uganda. Thus, we will only perform a short-run analysis for Rwanda. 
Table 5. Cointegration Tests

\begin{tabular}{cccc}
\hline Countries & ARDL structure & F-statistics & Remarks \\
\hline Burundi & $2,0,1,0,0$ & $\mathbf{7 . 5 0 7} * * *$ & Cointegrated \\
Kenya & $3,3,1,3,0$ & $\mathbf{5 . 3 2 4} * * *$ & Cointegrated \\
Rwanda & $1,2,0,1,0$ & 2.331 & Not cointegrated \\
Tanzania & $3,2,0,0,0$ & $\mathbf{9 . 8 0 8} * * *$ & Cointegrated \\
Uganda & $1,0,0,0,0$ & $\mathbf{4 . 0 3 2} * *$ & Cointegrated \\
\hline
\end{tabular}

(Notes) $*, * *$,and $* * *$ are significance levels of $10 \%, 5 \%$, and $1 \%$, respectively. ARDL is the autoregressive distributed lag.

Based on the ARDL cointegration test results, the error correction model (ECM) is adopted to investigate the four countries' speed of adjustment to the long-term equilibrium during a short-term shock. Moreover, the ECM also enables the study to assess the effects of variables on the conditioning information set on the short- and long-term money demand.

The ECM process has two steps. The first focuses on deriving the error correction term (ECT) by regressing the outcome variable on the independent variables and then subtracting the actual value of the dependent variable from the estimated value. This step is illustrated as follows:

$$
E C T=\ln (M / p)_{t}-\left(\vartheta_{0}+\vartheta_{1} T+\vartheta_{2} \ln y_{t}+\vartheta_{3} R_{t}^{d}+\vartheta_{4} I N F_{t}+\vartheta_{5} R_{t}^{f}+\vartheta_{6} \ln E_{t}\right)
$$

Then, a trend is introduced into the regression according to the variables' trending character. The ECT derived from Equation (4) is fitted into Equation (2) to obtain Equation (5), which is employed to estimate the ECM. The speed of adjustment is measured by the value of $\tau$.

This value is expected to display a negative sign to restore the long-term relationship after an exogenous shock and should range between 0 and -1 . The value of 0 indicates the absence of an adjustment. -1 shows complete adjustment, one period following the exogenous shock. Conversely, a positive value denotes the absence of convergence toward the long-term equilibrium after an exogenous shock. In other words, it reflects a permanent deviation from the equilibrium (Asongu, 2014e).

$$
\triangle \ln (M / p)_{t}=\gamma_{0}+\gamma_{1} \Delta l n y_{t}+\gamma_{2} \Delta R_{t}^{d}+\gamma_{3} I N F_{t}+\gamma_{4} \triangle R_{t}^{f}+\gamma_{5} \Delta \ln E_{t}+\tau E C T_{t-1}+\varepsilon_{t}
$$

This study aims to investigate the EAC's stability of money demand. Our findings are consistent with recent literature (Akinlo, 2006; Kumar, 2011; Khan \& Hye, 2013; Kumar et al., 2013) in employing parameter consistency analyses through Brown et al.'s (1975) cumulative sum (CUSUM) and CUSUM squared (CUSUMSQ) tests. The CUSUM test is linked to the 
cumulative recursive sum of recursive residuals, whereas the CUSUMSQ test pertains to the cumulative sum of squares of recursive residuals. The null hypothesis (i.e., the position of instability) is rejected when the plots related to the CUSUM and CUSUMSQ tests are significant at the $5 \%$ level. Consequently, when the corresponding plots fall outside the $5 \%$ critical lines, the money demand function is not stable.

\section{Empirical Results}

Table 6 shows short-and long-run relationships between broad money aggregate and its determinants. Accordingly, the ARDL estimation approach articulates the impacts of exchange rate, interest rate, and inflation on the EAC member states' money demand. Columns (2)-(6) of Table 6 present the findings of respective countries, whereas column (7) presents the panel evidence (i.e., combining the five member states). Unlike other EAC countries for which both short- and long-term relationships are apparent, the findings for Rwanda are exclusively in terms of short-run effects because we could not establish its cointegration relationship. This finding is consistent with Drummond et al. (2015b) who have concluded that Rwanda should be excluded from the proposed union because of its incapacity to cushion asymmetric shocks.

Table 6 shows that influencing money demand varies in the EAC. In the short run, income increase has a significant contemporary negative effect on Rwanda's money demand. By contrast, the contemporary effect of income change on Kenya and Tanzania is insignificantly positive. However, the first lag of income change significantly and negatively impacts Tanzania's money demand, whereas the second lag of income change negatively impacts Kenya's money demand. Furthermore, the results show that short-term inflation rate change significantly, and negatively impact Burundi and Uganda's money demand but insignificantly impact that of Kenya and Tanzania.

In addition, exchange rate changes significantly and positively impact Burundi and Tanzania's money demand but significantly negatively that of Kenya and Uganda. Foreign interest rate (UKINTEREST) insignificantly affects the five countries' short-term money demand. The value of the ECT coefficient significantly varies across the five countries. Similarly, the ECT coefficient has a negative sign as expected. Based on the ECT coefficient value, it can be deduced that during an asymmetric shock, Kenya is the fastest to restore its long-run equilibrium, followed by Tanzania and Burundi. Uganda cannot cushion asymmetric shocks and restore long-term equilibrium, whereas restoration is not applicable to Rwanda because of the absence of a cointegration relationship.

The long-term results show that income significantly and positively impact Kenya and Tanzania's money demand, whereas insignificant affects that of Burundi and Uganda. Particularly, the results show that income increase in Kenya and Tanzania over-proportionately increases long-term money demand. Furthermore, inflation rate significantly and negatively impacts Burundi's 
Table 6. Long- and Short-Term Effects

\begin{tabular}{|c|c|c|c|c|c|c|}
\hline & Burundi & Kenya & Rwanda & Tanzania & Uganda & ALL \\
\hline \multicolumn{7}{|l|}{ Long-run estimation } \\
\hline Constant & $\begin{array}{c}12.203 \\
(11.659)\end{array}$ & $\begin{array}{r}-10.825 \\
(3.905)\end{array}$ & & $\begin{array}{c}-8.392 * * * \\
(1.992)\end{array}$ & $\begin{array}{c}76.763 \\
(371.437)\end{array}$ & $\begin{array}{c}0.460 \div * * \\
(0.094)\end{array}$ \\
\hline LRGDP & $\begin{array}{c}0.330 \\
(0.523)\end{array}$ & $\begin{array}{c}1.408 * * * \\
(0.173)\end{array}$ & & $\begin{array}{c}1.248 * * * \\
(0.079)\end{array}$ & $\begin{array}{c}-1.628 \\
(12.706)\end{array}$ & $\begin{array}{c}0.842 * * * \\
(0.130)\end{array}$ \\
\hline INFL & $\begin{array}{c}-0.037 * \\
(0.021)\end{array}$ & $\begin{array}{c}0.003 \\
(0.002)\end{array}$ & & $\begin{array}{c}0.001 \\
(0.003)\end{array}$ & $\begin{array}{l}-0.074 \\
(0.311)\end{array}$ & $\begin{array}{c}-0.017 * * \\
(0.007)\end{array}$ \\
\hline LEXCH & $\begin{array}{c}0.363 * * \\
(0.171)\end{array}$ & $\begin{array}{c}0.042 \\
(0.057)\end{array}$ & & $\begin{array}{c}0.084 * * * \\
(0.020)\end{array}$ & $\begin{array}{l}-0.700 \\
(2.838)\end{array}$ & $\begin{array}{c}0.061 \\
(0.061)\end{array}$ \\
\hline UKINTEREST & $\begin{array}{c}0.007 \\
(0.028)\end{array}$ & $\begin{array}{c}0.009 \\
(0.009)\end{array}$ & & $\begin{array}{c}0.008 \\
(0.008)\end{array}$ & $\begin{array}{l}-0.194 \\
(0.744)\end{array}$ & $\begin{array}{c}-0.042 * * \\
(0.016)\end{array}$ \\
\hline \multicolumn{7}{|l|}{ Short-run estimation } \\
\hline$\triangle \mathrm{LRM} 2(-1)$ & $\begin{array}{c}-0.398 * * \\
(0.164)\end{array}$ & $\begin{array}{c}0.580 \div * \\
(0.222)\end{array}$ & & $\begin{array}{c}0.574 * * * \\
(0.121)\end{array}$ & & \\
\hline$\triangle \mathrm{LRM} 2(-2)$ & & $\begin{array}{c}0.488 \div * \\
(0.176)\end{array}$ & & $\begin{array}{c}0.547^{* * *} \\
(0.136)\end{array}$ & & \\
\hline$\triangle \mathrm{LRGDP}$ & $\begin{array}{c}0.109 \\
(0.207)\end{array}$ & $\begin{array}{c}0.027 \\
(0.488)\end{array}$ & $\begin{array}{c}0.477 * * * \\
(0.098)\end{array}$ & $\begin{array}{c}0.373 \\
(0.631)\end{array}$ & $\begin{array}{l}-0.061 \\
(0.240)\end{array}$ & $\begin{array}{c}0.050 \\
(0.547)\end{array}$ \\
\hline$\triangle \mathrm{LRGDP}(-1)$ & & $\begin{array}{c}1.272 \\
(0.745)\end{array}$ & & $\begin{array}{c}-2.944 * * * \\
(0.619)\end{array}$ & & \\
\hline$\triangle \mathrm{LRGDP}(-2)$ & & $\begin{array}{c}-2.116 * * * \\
(0.706)\end{array}$ & & & & \\
\hline$\triangle \mathrm{INFL}$ & $\begin{array}{c}-0.006 * * \\
(0.002)\end{array}$ & $\begin{array}{c}-0.001 \\
(0.001)\end{array}$ & $\begin{array}{c}0.000 \\
(0.001)\end{array}$ & $\begin{array}{c}0.000 \\
(0.002)\end{array}$ & $\begin{array}{c}-0.003 * * * \\
(0.001)\end{array}$ & $\begin{array}{c}0.000 \\
(0.001)\end{array}$ \\
\hline$\triangle \mathrm{LEXCH}$ & $\begin{array}{c}0.120 * * * * \\
(0.039)\end{array}$ & $\begin{array}{c}-0.183 \\
(0.114)\end{array}$ & $\begin{array}{c}-0.257 * * \\
(0.115)\end{array}$ & $\begin{array}{c}0.054 * * * \\
(0.015)\end{array}$ & $\begin{array}{c}-0.026 * \\
(0.015)\end{array}$ & $\begin{array}{c}0.041 \\
(0.046)\end{array}$ \\
\hline$\triangle \mathrm{LEXCH}(-1)$ & & $\begin{array}{c}-0.256^{* *} \\
(0.119)\end{array}$ & & & & \\
\hline$\triangle \mathrm{LEXCH}(-2)$ & & $\begin{array}{c}0.105 \\
(0.105)\end{array}$ & & & & \\
\hline$\triangle$ UKINTEREST & $\begin{array}{c}0.002 \\
(0.009)\end{array}$ & $\begin{array}{c}0.007 \\
(0.007)\end{array}$ & $\begin{array}{c}0.005 \\
(0.009)\end{array}$ & $\begin{array}{c}0.005 \\
(0.005)\end{array}$ & $\begin{array}{l}-0.007 \\
(0.014)\end{array}$ & $\begin{array}{l}-0.001 \\
(0.005)\end{array}$ \\
\hline ECT & $\begin{array}{c}-0.331 * * \\
(0.141)\end{array}$ & $\begin{array}{c}-0.858 \div * * \\
(0.216)\end{array}$ & & $\begin{array}{c}-0.652 * * * \\
(0.128)\end{array}$ & $\begin{array}{l}-0.037 \\
(0.150)\end{array}$ & $\begin{array}{c}-0.183 \div * \frac{1}{} \\
(0.049)\end{array}$ \\
\hline R-squared & 0.932 & 0.990 & 0.482 & 0.995 & 0.982 & \\
\hline Normality & 0.791 & 0.181 & 0.458 & 0.132 & 0.350 & \\
\hline $\mathrm{ARCH}$ test & $\begin{array}{l}\text { (1) } 0.582 \\
\text { (3) } 0.359\end{array}$ & $\begin{array}{l}\text { (1) } 0.067 \\
\text { (3) } 0.854\end{array}$ & $\begin{array}{l}\text { (1) } 0.892 \\
\text { (3) } 0.224\end{array}$ & $\begin{array}{l}\text { (1) } 0.633 \\
\text { (3) } 0.695\end{array}$ & $\begin{array}{l}\text { (1) } 0.227 \\
\text { (3) } 0.252\end{array}$ & \\
\hline BG LM test & $\begin{array}{l}\text { (1) } 0.754 \\
\text { (3) } 0.688\end{array}$ & $\begin{array}{l}\text { (1) } 0.012 \\
\text { (3) } 0.011\end{array}$ & $\begin{array}{l}\text { (1) } 0.601 \\
\text { (3) } 0.516\end{array}$ & $\begin{array}{l}\text { (1) } 0.078 \\
\text { (3) } 0.002\end{array}$ & $\begin{array}{l}\text { (1) } 0.104 \\
\text { (3) } 0.121\end{array}$ & \\
\hline CUSUM & Stable & Stable & Stable & Stable & Not stable & \\
\hline CUSUMSQ & Stable & Not stable & Stable & stable & Stable & \\
\hline
\end{tabular}

(Notes) $*, * *$,and $* * *$ are significance levels of $10 \%, 5 \%$, and $1 \%$, respectively. RM2 is the real broad money; RGDP is the real GDP; INFL is the inflation rate based on the GDP deflator; EXCH is the exchange rate; UKINTEREST is the UK interest rate; ECT is the error correction term; CUSUM is the cumulative sum; and CUSUMSQ is the CUSUM of square. The reported values in parentheses are the standard errors. The reported values for normality test, $\mathrm{ARCH}$ test, and BG LM test are the probability values of the F-statistics. BG is the Breusch-Godfrey serial correlation LM test 
money demand, whereas insignificantly affect that of other countries. This finding suggests that as the opportunity cost of holding money increases, Burundi's money demand reduces.

Furthermore, we find that exchange rate increase significantly and positively impacts Burundi and Tanzania's money demand but insignificantly impact that of Kenya and Uganda. The findings suggest that Burundi and Tanzania's currency substitution and exchange rate appreciation are associated. In addition, we find that foreign interest rate insignificantly affects all five member states' money demand. This finding is consistent with Bahmani-Oskooee and Rehman (2005) and Folarin and Asongu (2019), who have established that interest rate cannot appropriately measure an opportunity variable in developing countries with less-developed financial markets.

The last column of Table 6 presents the panel evidence indicating that income positively and significantly impacts money demand and inflation and foreign interest rates negatively and significantly impact money demand, whereas exchange rate effect is insignificant. These findings imply that money demand increases with income increase, which is a scale variable. By contrast, money demand increases with inflation and foreign interest rates reduction, which are opportunity variables.

The results of the stability of money demand function in Figure 1 reveal the EAC member states' divergence. The results show that Burundi, Rwanda, and Tanzania have stable money demand based on the CUSUM and CUSUMSQ tests. The remaining two countries have partial stability only because one of the two tests reveals instability. Kenya's money demand is stable based on the CUSUM test but unstable based on the CUSUMSQ test. In contrast, Uganda's money demand is unstable based on the CUSUM test but stable based on the CUSUMSQ test. 
Figure 1. Stability test results
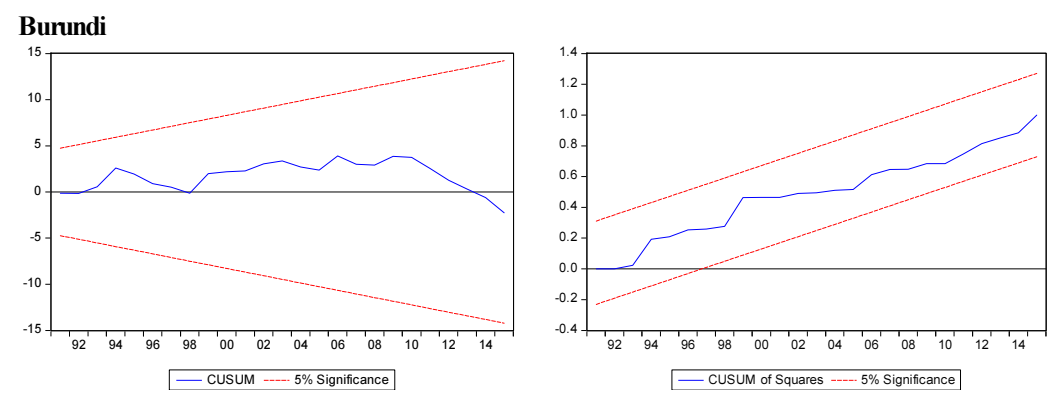

\section{Kenya}
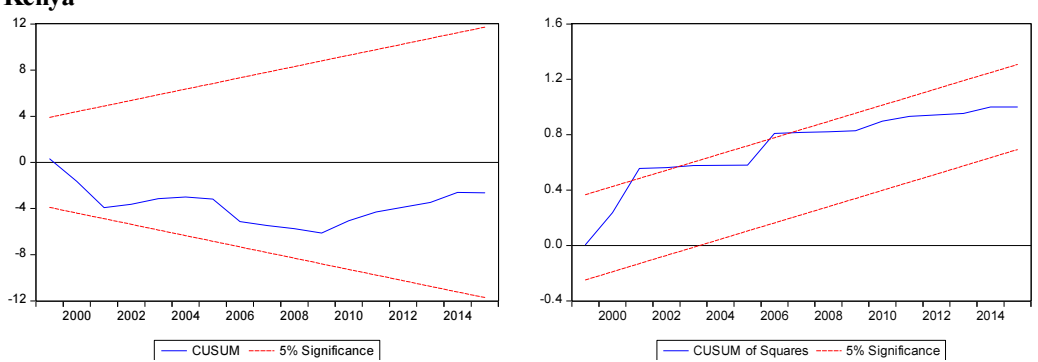

\section{Rwanda}

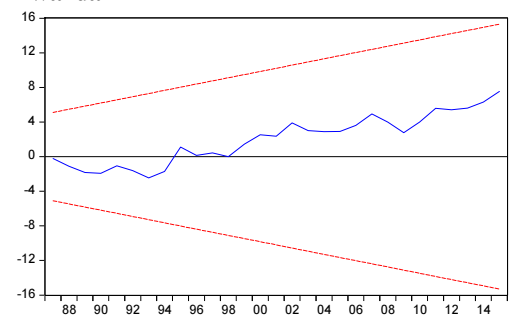

- CUSUM -... $5 \%$ significance

\section{Tanzania}
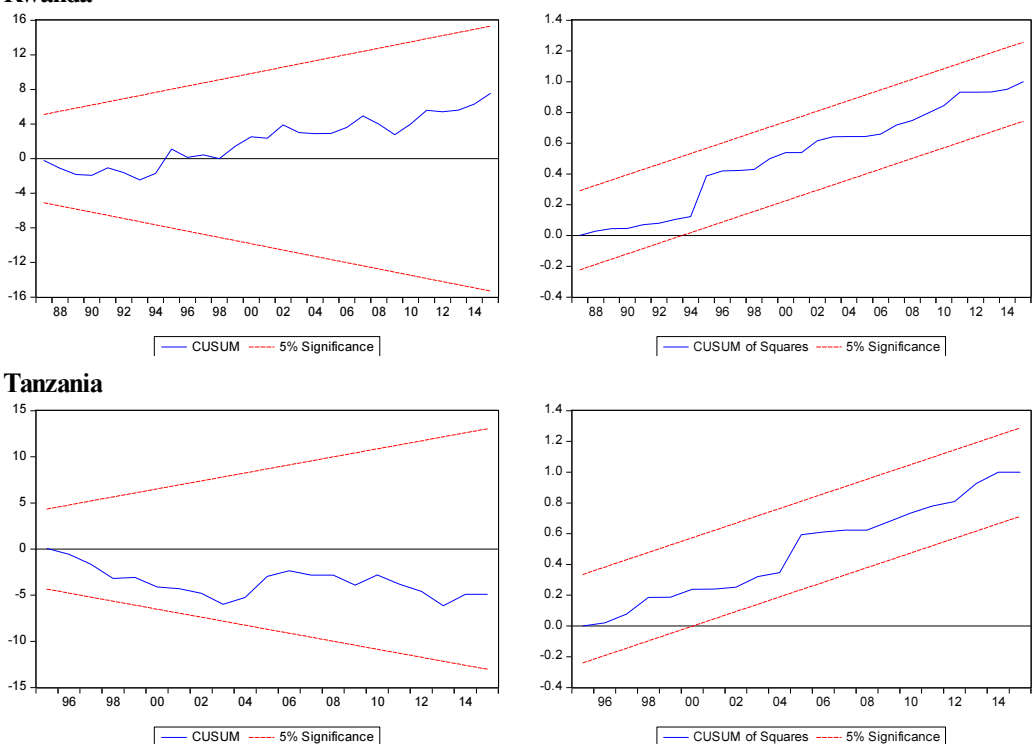

- CUSUM of Squares ----. 5\% Significance

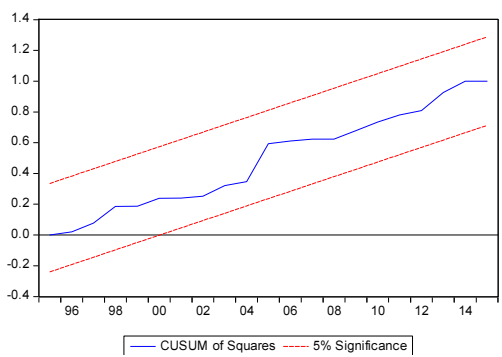

\section{Uganda}
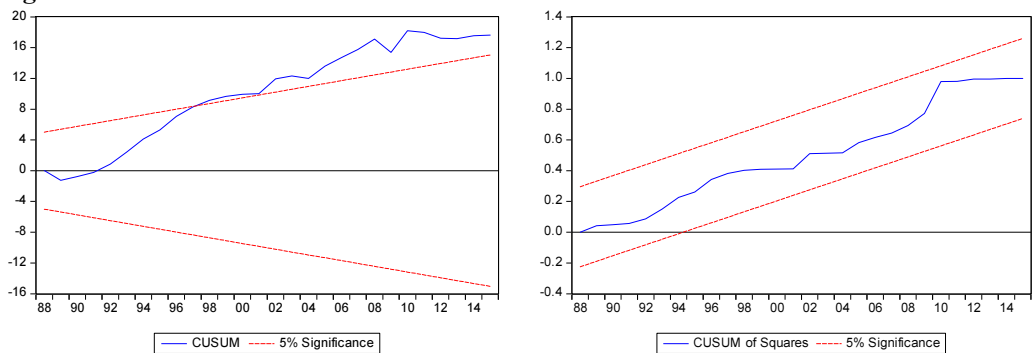


\section{Additional Analysis}

We employed $M 2$ in the main estimation as the main measure of monetary aggregate. $M 1$ is selected over $M 2$ because it reflects African countries' actual condition given the technological advancements. However, $M 2$ equals $M 1$ plus near money, and near money comprises of money market securities, mutual funds, and time deposits, whereas $M 1$ is currency in circulation and demand deposits. Thus, $M 1$ is more liquid than $M 2$. Therefore, we re-estimate the main equation using $M 1$ to understand the impacts of liquidity on the money demand function. We begin with the ARDL estimation and then the ECM analysis with the corresponding results presented in Tables 7 and 8, respectively.

Table 7 presents the ARDL cointegration test result indicating that a long-term relationship holds for four countries: Burundi, Kenya, Rwanda, and Tanzania. Burundi, Kenya, and Tanzania also exhibited a long-run relationship when $M 2$ was used to measure monetary aggregate. Table 8 presents the ECM estimation results, which did not deviate from the results reported in Table 6 in terms of divergence in the stability of money demand in the selected countries and the response of money demand to changes in the dependent variables.

Table 7. Cointegration Tests

\begin{tabular}{cccc}
\hline Countries & ARDL structure & F-statistics & Remarks \\
\hline Burundi & $2,0,1,1,2$ & $\mathbf{6 . 9 1 6 * * *}$ & Cointegrated \\
Kenya & $1,3,3,3,3$ & $\mathbf{8 . 3 4 5 * * *}$ & Cointegrated \\
Rwanda & $1,3,0,1,0$ & $\mathbf{7 . 6 5 6 * * *}$ & Cointegrated \\
Tanzania & $2,0,0,1,3$ & $\mathbf{6 . 1 9 8 * * *}$ & Cointegrated \\
Uganda & $1,0,0,0,0$ & 2.289 & No-Cointegrated \\
\hline
\end{tabular}

(Notes) $*, * *$,and ${ }^{* * *}$ are significance levels of $10 \%, 5 \%$, and $1 \%$, respectively. ARDL: autoregressive distributed lag

Table 8. Long- and Short-Term Effects

\begin{tabular}{|c|c|c|c|c|c|c|}
\hline & Burundi & Kenya & Rwanda & Tanzania & Uganda & ALL \\
\hline \multicolumn{7}{|l|}{ Long-run estimation } \\
\hline Constant & $\begin{array}{l}15.853 \\
(7.511)\end{array}$ & $\begin{array}{l}-42.523 \\
(11.726)\end{array}$ & $\begin{array}{c}8.410 \div \div * \\
(1.493)\end{array}$ & $\begin{array}{c}-21.407 \div * \\
(9.137)\end{array}$ & & $\begin{array}{c}3.232 \div * * \\
(0.311)\end{array}$ \\
\hline LRGDP & $\begin{array}{c}0.175 \\
(0.347)\end{array}$ & $\begin{array}{c}2.758 * * * \\
(0.502)\end{array}$ & $\begin{array}{c}0.524 * * * \\
(0.062)\end{array}$ & $\begin{array}{c}1.699 \div * * \\
(0.317)\end{array}$ & & $\begin{array}{c}0.477 \div * * \\
(0.105)\end{array}$ \\
\hline INFL & $\begin{array}{c}-0.024^{* *} \\
(0.009)\end{array}$ & $\begin{array}{c}-0.022 * * \\
(0.008)\end{array}$ & $\begin{array}{c}-0.006 * \\
(0.003)\end{array}$ & $\begin{array}{l}-0.0134 \\
(0.017)\end{array}$ & & $\begin{array}{c}0.005^{* *} \\
(0.002)\end{array}$ \\
\hline $\mathrm{LEXCH}$ & $\begin{array}{c}0.301 * * \\
(0.141)\end{array}$ & $\begin{array}{l}-0.243 \\
(0.141)\end{array}$ & $\begin{array}{c}0.134 * * \\
(0.065)\end{array}$ & $\begin{array}{c}0.114 \\
(0.172)\end{array}$ & & $\begin{array}{l}-0.011 \\
(0.030)\end{array}$ \\
\hline UKINTEREST & $\begin{array}{c}0.006 \\
(0.026)\end{array}$ & $\begin{array}{l}0.085 * \\
(0.042)\end{array}$ & $\begin{array}{l}-0.010 \\
(0.011)\end{array}$ & $\begin{array}{c}0.104 \\
(0.072)\end{array}$ & & $\begin{array}{c}-0.020 * \\
(0.011)\end{array}$ \\
\hline
\end{tabular}


Table 8. Continued

\begin{tabular}{|c|c|c|c|c|c|c|}
\hline & Burundi & Kenya & Rwanda & Tanzania & Uganda & ALL \\
\hline \multicolumn{7}{|l|}{ Short-run estimation } \\
\hline$\triangle \mathrm{LRM} 1(-1)$ & $\begin{array}{c}-0.409 * * \\
(0.171)\end{array}$ & & & $\begin{array}{c}0.292 * * \\
(0.122)\end{array}$ & & \\
\hline$\triangle \mathrm{LRGDP}$ & $\begin{array}{c}0.071 \\
(0.158)\end{array}$ & $\begin{array}{c}0.163 \\
(0.637)\end{array}$ & $\begin{array}{c}0.222 * * * \\
(0.062)\end{array}$ & $\begin{array}{l}0.520 * * \\
(0.227)\end{array}$ & $\begin{array}{l}-2.035 \\
(1.631)\end{array}$ & $\begin{array}{l}0.556 * \\
(0.298)\end{array}$ \\
\hline$\triangle \mathrm{LRGDP}(-1)$ & & $\begin{array}{l}2.563 * \\
(1.442)\end{array}$ & $\begin{array}{c}-0.371 \div * * \\
(0.70)\end{array}$ & & & \\
\hline$\triangle \mathrm{LRGDP}(-2)$ & & $\begin{array}{c}-3.016 * * \\
(1.193)\end{array}$ & $\begin{array}{c}-0.226 * * \\
(0.084)\end{array}$ & & & \\
\hline$\triangle \mathrm{INFL}$ & $\begin{array}{c}-0.004 * * \\
(0.002)\end{array}$ & $\begin{array}{l}-0.002 \\
(0.003)\end{array}$ & $\begin{array}{c}-0.003 * * \\
(0.002)\end{array}$ & $\begin{array}{c}-0.004 \\
(0.003)\end{array}$ & $\begin{array}{c}-0.001 \\
(0.001)\end{array}$ & $\begin{array}{c}-0.001 * * \\
(0.001)\end{array}$ \\
\hline$\triangle \mathrm{INFL}(-1)$ & & $\begin{array}{c}0.006 * * \\
(0.002)\end{array}$ & & & & \\
\hline$\triangle \mathrm{INFL}(-2)$ & & $\begin{array}{l}0.006 * \\
(0.003)\end{array}$ & & & & \\
\hline$\triangle \mathrm{LEXCH}$ & $\begin{array}{c}-0.492 * * \\
(0.202)\end{array}$ & $\begin{array}{c}-0.652 * * \\
(0.239)\end{array}$ & $\begin{array}{c}-0.500 * * * \\
(0.157)\end{array}$ & $\begin{array}{c}0.212 \\
(0.125)\end{array}$ & $\begin{array}{c}-0.215^{* *} \\
(0.024)\end{array}$ & $\begin{array}{l}-0.126 \\
(0.091)\end{array}$ \\
\hline$\triangle \mathrm{LEXCH}(-1)$ & & $\begin{array}{l}-0.061 \\
(0.139)\end{array}$ & & & & \\
\hline$\triangle \mathrm{LEXCH}(-2)$ & & $\begin{array}{l}-0.226 \\
(0.141)\end{array}$ & & & & \\
\hline$\triangle$ UKINTEREST & $\begin{array}{l}-0.014 \\
(0.009)\end{array}$ & $\begin{array}{l}-0.025 \\
(0.014)\end{array}$ & $\begin{array}{l}-0.006 \\
(0.007)\end{array}$ & $\begin{array}{l}0.013^{*} \\
(0.007)\end{array}$ & $\begin{array}{l}-0.009 \\
(0.024)\end{array}$ & $\begin{array}{c}-0.021 * * * \\
(0.003)\end{array}$ \\
\hline$\triangle$ UKINTEREST(-1) & $\begin{array}{l}-0.015 \\
(0.011)\end{array}$ & $\begin{array}{c}0.026 \\
(0.018)\end{array}$ & & $\begin{array}{c}0.019 \\
(0.014)\end{array}$ & & \\
\hline$\triangle$ UKINTEREST(-2) & & $\begin{array}{c}-0.050 * * \\
(0.019)\end{array}$ & & $\begin{array}{c}-0.033 * * * \\
(0.008)\end{array}$ & & \\
\hline ECT & $\begin{array}{c}-0.408 * * * \\
(0.131)\end{array}$ & $\begin{array}{c}-0.503 * * * \\
(0.153)\end{array}$ & $\begin{array}{c}-0.602 \div * * \\
(0.117)\end{array}$ & $\begin{array}{c}-0.306 \% \\
(0.173)\end{array}$ & & $\begin{array}{c}-0.334 * * * \\
(0.036)\end{array}$ \\
\hline R-squared & 0.942 & 0.979 & 0.973 & 0.989 & 0.037 & \\
\hline Normality & 0.854 & 0.631 & 0.697 & 0.289 & 0.018 & \\
\hline $\mathrm{ARCH}$ test & 0.598 & 0.083 & 0.822 & 0.624 & 0.422 & \\
\hline BG LM test & 0.404 & 0.140 & 0.036 & 0.198 & 0.121 & \\
\hline CUSUM & Stable & Stable & Stable & Stable & Stable & \\
\hline CUSUMSQ & Stable & Not stable & Stable & Not stable & Not stable & \\
\hline
\end{tabular}

(Notes) $*, * *$, and $* * *$ are significance levels of $10 \%, 5 \%$, and $1 \%$, respectively. RM1 is the real narrow money; RGDP is the real GDP; INFL is the inflation rate based on the GDP deflator; EXCH is the exchange rate; UKINTEREST is the UK interest rate; ECT is the error correct term; CUSUM is the cumulative sum; and CUSUMSQ is the CUSUM of square. The reported values in parentheses are the standard errors. The reported values for normality test, ARCH test, and BG LM test are the probability values of the F-statistics. BG is the Breusch-Godfrey serial correlation LM test.

In addition to the use of an alternative monetary aggregate measure, we also use Gregory and Hansen's (1996) cointegration test. The approach incorporates structural breaks into the 
modeling of the cointegration estimation, which is important because economic structural changes, as sources of structural shifts, may alter the results obtained.

Table 9 reports the study findings, which should be interpreted with caution due to the limited number of observations used in the study. A typical Gregory and Hansen (1996) cointegration test requires several observations. However, we are limited by data availability. The Gregory and Hansen (1996) cointegration framework has three tests, namely, the ADF, $Z_{t}^{*}$, and $Z_{\alpha}^{*}$ test types. The properties of each test are reported in Gregory and Hansen (1996). Moreover, the structural change could be modeled in three ways with intercept, trend, and regime shift features, respectively. Table 9 shows that by incorporating structural breaks, co-integrating relationships in most countries are not established, unlike when the ARDL was used. However, the results support our initial idea about the divergence in the stability condition of the selected countries within the proposed EAMU bloc.

Table 9. Gregory and Hansen (1996) Cointegration Test Result

\begin{tabular}{|c|c|c|c|c|c|c|c|c|c|c|c|c|c|}
\hline & & \multicolumn{6}{|c|}{ M2 } & \multicolumn{6}{|c|}{ M1 } \\
\hline & & \multicolumn{2}{|c|}{$\mathrm{ADF}$} & \multicolumn{2}{|c|}{$Z_{t}^{*}$} & \multicolumn{2}{|c|}{$Z_{\alpha}^{*}$} & \multicolumn{2}{|c|}{$\mathrm{ADF}$} & \multicolumn{2}{|c|}{$Z_{t}^{*}$} & \multicolumn{2}{|c|}{$Z_{\alpha}^{*}$} \\
\hline & & $\begin{array}{c}\text { Test } \\
\text { statistics }\end{array}$ & $\begin{array}{c}\text { Break } \\
\text { date }\end{array}$ & $\begin{array}{c}\text { Test } \\
\text { statistics }\end{array}$ & $\begin{array}{c}\text { Break } \\
\text { date }\end{array}$ & $\begin{array}{c}\text { Test } \\
\text { statistics }\end{array}$ & $\begin{array}{c}\text { Break } \\
\text { date }\end{array}$ & $\begin{array}{c}\text { Test } \\
\text { statistics }\end{array}$ & $\begin{array}{c}\text { Break } \\
\text { date }\end{array}$ & $\begin{array}{c}\text { Test } \\
\text { statistics }\end{array}$ & $\begin{array}{c}\text { Break } \\
\text { date }\end{array}$ & $\begin{array}{c}\text { Test } \\
\text { statistics }\end{array}$ & $\begin{array}{c}\text { Break } \\
\text { date }\end{array}$ \\
\hline \multirow{3}{*}{ Burundi } & $\mathrm{C}$ & -4.28 & 2010 & -4.38 & 2010 & -24.79 & 2010 & -3.87 & 2003 & -3.93 & 2003 & -23.64 & 2003 \\
\hline & $\mathrm{C} / \mathrm{T}$ & -4.75 & 2010 & -4.82 & 2010 & -28.56 & 2010 & -3.85 & 2003 & -3.91 & 2002 & -32.07 & 2002 \\
\hline & $\mathrm{C} / \mathrm{S}$ & -5.28 & 2002 & -5.36 & 2002 & -31.23 & 2002 & -5.28 & 2002 & -5.45 & 2002 & -32.07 & 2002 \\
\hline \multirow{3}{*}{ Kenya } & $\mathrm{C}$ & $-5.64 * *$ & 2005 & $-5.63 * *$ & 2005 & -32.63 & 2005 & -3.75 & 2001 & -3.81 & 2001 & -20.92 & 2001 \\
\hline & $\mathrm{C} / \mathrm{T}$ & $-5.83^{*}$ & 2001 & $-5.75 *$ & 2001 & -32.80 & 2001 & $-5.43^{*}$ & 1994 & $-5.51 *$ & 1994 & -32.01 & 1994 \\
\hline & $\mathrm{C} / \mathrm{S}$ & -6.04 & 2002 & -6.04 & 2002 & -35.17 & 2002 & -3.61 & 2001 & -3.67 & 2001 & -19.85 & 2001 \\
\hline \multirow{3}{*}{ Rwanda } & $\mathrm{C}$ & -4.52 & 1985 & -4.67 & 1985 & -29.12 & 1985 & -5.08 & 1992 & -5.16 & 1992 & -31.03 & 1992 \\
\hline & $\mathrm{C} / \mathrm{T}$ & -5.22 & 1990 & -4.84 & 1990 & -29.64 & 1990 & $-5.95^{* *}$ & 1988 & $-6.04 * *$ & 1988 & -34.24 & 1988 \\
\hline & $\mathrm{C} / \mathrm{S}$ & -4.98 & 1989 & -5.06 & 1989 & -32.50 & 1989 & $-6.88 * *$ & 1992 & $-6.98 * * *$ & 1992 & -41.81 & 1992 \\
\hline \multirow{3}{*}{ Tanzania } & $\mathrm{C}$ & -4.52 & 1995 & -3.94 & 1996 & -20.97 & 1996 & -5.06 & 1988 & -4.96 & 1988 & -20.18 & 1988 \\
\hline & $\mathrm{C} / \mathrm{T}$ & -4.79 & 2002 & -4.51 & 2001 & -25.65 & 2001 & -4.71 & 1985 & -5.06 & 1985 & -19.66 & 1985 \\
\hline & $\mathrm{C} / \mathrm{S}$ & -4.91 & 1999 & -4.98 & 1996 & -29.51 & 1996 & -4.93 & 2006 & -4.80 & 1994 & -23.09 & 1994 \\
\hline \multirow{3}{*}{ Uganda } & $\mathrm{C}$ & $-5.38^{*}$ & 2008 & -5.18 & 1987 & -30.98 & 1987 & -4.98 & 2008 & -4.81 & 2007 & -28.39 & 2007 \\
\hline & $\mathrm{C} / \mathrm{T}$ & -4.25 & 2010 & -4.49 & 2010 & -26.56 & 2010 & $-6.40 * * *$ & 2010 & $-5.91 * *$ & 2010 & -34.98 & 2010 \\
\hline & $\mathrm{C} / \mathrm{S}$ & $-6.51^{* *}$ & 2003 & -4.82 & 1994 & -29.05 & 1994 & $-6.36^{*}$ & 2001 & -5.29 & 2000 & -30.15 & 2000 \\
\hline \multirow{5}{*}{$\begin{array}{l}\text { Critical } \\
\text { value }\end{array}$} & & \multicolumn{4}{|c|}{$\mathrm{ADF}$} & \multicolumn{4}{|c|}{$Z_{t}^{*}$} & \multicolumn{4}{|c|}{$Z_{\alpha}^{*}$} \\
\hline & & \multicolumn{3}{|c|}{$5 \%$} & $10 \%$ & $1 \%$ & \multicolumn{2}{|c|}{$5 \%$} & $10 \%$ & $1 \%$ & \multicolumn{2}{|c|}{$5 \%$} & $10 \%$ \\
\hline & $\mathrm{C}$ & -6.05 & \multicolumn{2}{|c|}{-5.56} & -5.31 & -6.05 & \multicolumn{2}{|c|}{-5.56} & -5.31 & -70.18 & \multicolumn{2}{|c|}{-59.40} & -54.38 \\
\hline & $\mathrm{C} / \mathrm{T}$ & -6.36 & \multicolumn{2}{|c|}{-5.83} & -5.59 & -6.36 & \multicolumn{2}{|c|}{-5.83} & -5.59 & -76.95 & \multicolumn{2}{|c|}{-65.44} & -60.12 \\
\hline & $\mathrm{C} / \mathrm{S}$ & -6.92 & \multicolumn{2}{|c|}{-6.41} & -6.17 & -6.92 & \multicolumn{2}{|c|}{-6.41} & -6.17 & -90.35 & \multicolumn{2}{|c|}{-78.52} & -75.56 \\
\hline
\end{tabular}

(Notes) $*, * *, * * *$ are significance levels of $10 \%, 5 \%$ and $1 \%$ respectively; $\mathrm{C}$ is intercept, $\mathrm{C} / \mathrm{T}$ is trend; $\mathrm{C} / \mathrm{S}$ is regime shift; $\mathrm{M} 1$ is real narrow money; M2 is real broad money and ADF is Augment Dickey Fuller. 


\section{Conclusion}

This study has investigated money demand stability in the proposed EAMU to complement the existing literature. The study uses annual data within 1981-2015 of the five countries constituting the EAC. A standard money demand function is designed and estimated using a bounds testing approach to cointegration and error correction modeling. The findings show that monetary stability across countries diverges. This divergence is articulated in terms of differences in CUSUM and CUSUMSQ tests, short- and long-term determinants, and error correction during a shock. The results show that Burundi, Rwanda, and Tanzania have stable money demand based on the CUSUM and CUSUMSQ tests, whereas remaining countries, namely, Kenya and Uganda, have partial stability only. During a shock, Kenya is the fastest to restore its long-run equilibrium, followed by Tanzania and Burundi. Uganda cannot cushion asymmetric shocks and restore long-term equilibrium, whereas Rwanda cannot possibly restore because of the absence of a cointegration relationship. Thus, Rwanda and Uganda may be excluded from the proposed union. The reason is because evidence shows a panel-based error correction mechanism, which is fundamentally driven by three countries. We discuss below policy implications based on the convergence needed for the proposed EAMU's feasibility.

Based on macroeconomic fundamental differences of money demand, member states' convergence may improve through enhanced trade integration and reliable and accessible infrastructure. Moreover, conducive trade and institutional environments are important to the EMU to enhance trade and trade benefits from the potential monetary integration (UNCTAD, 2014; Asongu et al., 2017). Apart from these broader and common policy harmonizing recommendations, country-specific policies are also worthwhile. For instance, in the short run, Kenya and Tanzania need to establish a significant connection between inflation and money demand, whereas Uganda and Burundi are not associated with the underlying short-run policy concern. This condition is because inflation must significantly impact all member states' money demand to harmonize monetary policies across countries.

The timing of the effects of money demand determinants is also important in policy harmonization as non-contemporary determinants must be aligned for monetary policy effectiveness. Thus, as we have established, money demand determinants are contingent on the lag structure of corresponding determinants. For instance, income effect on money demand in the short run is contemporary in Rwanda whereas non-contemporary in Kenya and Tanzania. The non-contemporary effect is also contingent on the two lags for Kenya and one for Tanzania.

The quantity theory of money holds that output and price changes that affect money supply variations is more feasible when the velocity of money is stable. The recent EMU crisis implies the importance of stable macroeconomic policies to the proposed African monetary unions. Hence, countries such as Kenya and Uganda reflecting only partial stability in money demand 
need to significantly consolidate the stability of their money demand functions.

Other significant measures to improve convergence include (i) adjusting money demand determinants to country-specific monetary policies, (ii) constructing institutions that can enforce fiscal discipline and macroeconomic surveillance, (iii) building robust institutional networks that can consolidate financial, monetary, and fiscal stability, (iv) introducing a common basket currency alongside member states currencies as an alternative to fast-track the single currency process, and (v) implementing structural reforms that address policy and infrastructure needs. These recommendations are on the basis that the lack of convergence can be traceable to member states' high economic performance and absence of "political will "to sustain common currency commitment (see Kuteesa, 2012). Therefore, revisiting certain proposed benchmarks to monetary convergence is worthwhile.

Divergence could also result from information asymmetry on the proposed benchmarks and objectives of convergence in money demand. Nevertheless, this information asymmetry can be reduced by sharing relevant information that can be facilitated by data collection facilities, harmonizing statistics, improving competences and skills, and bridging technology gaps. Future research can focus on how information asymmetry reduction improves the proposed EAMU's feasibility.

\section{References}

Akinlo, A. E. (2006). The stability of money demand in Nigeria: An autoregressive distributed lag approach. Journal of Policy Modelling, 28(4), 445-452.

Anoruo, E. (2002). Stability of the Nigerian M2 money demand function in the SAP period. Economics Bulletin, 14(3), 1-9.

Asongu, S. A. (2013a). Real and monetary policy convergence: EMU crisis to the CFA zone. Journal of Financial Economic Policy, 5(1), 20-38.

Asongu, S. A. (2013b). A short-run Schumpeterian Trip to Embryonic African monetary zones. Economics Bulletin, 33(1), 859-873.

Asongu, S. A. (2014a). REER imbalances and macroeconomic adjustments in the proposed West African monetary union. South African Journal of Economics, 82(2), 276-289.

Asongu, S. A. (2014b). Are proposed African monetary unions optimal currency areas? Real, monetary and fiscal policy convergence analysis. African Journal of Economics and Management Studies, 5(1), 9-29.

Asongu, S. A. (2014c). How would monetary policy matter in the proposed African monetary unions? Evidence fromoutput and prices. African Finance Journal, 16(2), 34-63.

Asongu, S. A. (2014d). Linkages between investment flows and financial development: Causality evidence from selected African countries. African Journal of Economic and Management Studies, 5(3), 269-299.

Asongu, S. A. (2014e). Does money matter in Africa? New empirics on long-and short-run effects of 
monetary policy on output and prices. Indian Growth and Development Review, 7(2), 142-180. Asongu, S. A. (2015). Liberalisation and financial sector competition: A critical contribution to the empirics with an African assessment. South African Journal of Economics, 83(3), 425-451.

Asongu, S. A. (2016). New empirics of monetary policy dynamics: Evidence from the CFA franc zones. African Journal of Economic and Management Studies, 7(2), 164-204.

Asongu, S. A., Folarin, O. E., \& Biekpe, N. (2019a). The long run stability of money demand in the proposed West African monetary union. Research in International Business and Finance, 48(April), 483-495.

Asongu, S. A., Folarin, O. E., \& Biekpe, N. (2019b). The stability of demand for money in the proposed Southern African Monetary Union. International Journal of Emerging Markets, 15(2), 222-244.

Asongu, S. A., Nwachukwu, J. C., \& Tchamyou, V. S. (2017). A literature survey on the proposed African Monetary Unions. Journal of Economic Surveys, 31(3), 878-902.

Bahmani-Oskooee, M., \& Gelan, A. (2009). How stable is the demand for money in African countries? Journal of Economic Studies, 36(3), 216-235.

Bahmani-Oskooee, M., \& Rehman, H. (2005). Stability of the money demand function in Asian developing countries. Applied Economics, 37(7), 773-792.

Bangaké, C. (2008). Exchange rate volatility and optimum currency area: Evidence from Africa. Economics Bulletin, 6(12), 1-10.

Batuo, M. E., \& Asongu, S. A. (2015). The impact of liberalisation policies on income inequality in African countries. Journal of Economic Studies, 42(1), 68-100.

Brown, R. L., Durbin, J., \& Evans, J. M. (1975). Techniques for testing the constancy of regression relations over time. Journal of the Royal Statistical Society, 37(2), 149-192.

Buigut, S. (2011). A fast-track East African Community monetary union? Convergence evidence from a cointegration analysis. International Journal of Economics and Finance, 3(1), 255-261.

Buigut, S. K., \& Valev, N. T. (2005). Is the proposed East African monetary union an optimal currency area? A structural vector autoregression analysis. World Development, 33(12), 260-267.

Buigut, S., \& Valev, N. T. (2009). Benefits from mutual restraint in a multilateral monetary union. World Development, 37(3), 585-594.

Cavoli, T., \& Rajan, R. S. (2008). Open economy inflation targeting arrangements and monetary policy rules. Application to India. Indian Growth and Development Review, 1(2), 237-251.

Chaisrisawatsuk, S., Sharma, S. C., \& Chowdhury, A. R. (2004). Money demand stability under currency substitution: Some recent evidence. Applied Financial Economics, 14(1), 19-27.

Cristadoro, R., \& Veronese, G. (2011). Monetary policy in India: Is something amiss? Indian Growth and Development Review, 4(2), 166-192.

Davoodi, H. R., Dixit, S., \& Pinter, G. (2013). Monetary transmission mechanism in the East African Community: An empirical investigation (IMF Working Paper No. 13/39). Washington.

Drama, B. H. G., \& Yao, S. (2010). The demand for money in Cote d'Ivoire: Evidence from the cointegration test (MPRA Paper No. 20131), Munich.

Drummond, P., Wajid, S. K., \& Williams, O. (2015a). The Quest for Regional Integration in the East African Community. IMF Press.

Drummond, P., Aisen, A., Alper, E., Fuli, E., \& Walker, S. (2015b). Toward a Monetary Union in the 
East African Community Asymmetric Shocks, Exchange Rates, and Risk-Sharing Mechanisms. African Department Paper, IMF. Retrieved June 24, 2016, https://www.imf.org/external/pubs/ft/dp/2015/afr150 6.pdf

Falagiarda, M. (2010). Are the East African countries ready for a common currency? Traditional indicators and cointegration analysis. School of Economics of the University of Reading. Retrieved September 13, 2015, from http://www.tn.auf.org/CEAFE/Papiers_CEAFE10/Monnaie/Falagiarda.pdf

Folarin, O. E., \& Asongu, S. A. (2019). Financial liberalization and long-run stability of money demand in Nigeria. Journal of Policy Modeling, 41(5), 963-980.

Ghironi, F., \& Rebucci, A. (2000). Monetary rules for emerging market economies (Working Paper No. 476). Boston College Economics Department.

Gregory, A. W., \& Hansen, B. E. (1996). Residual-based tests for cointegration in models with regime shifts. Journal of Econometrics, 70, 99-126.

Halicioglu, F., \& Ugur, M. (2005). On stability of the demand for money in a developing OECD country: the case of Turkey. Global Business and Economics Review, 7(2), 203-213.

Hossain, A. (1993). Financial reforms, stability of the money demand and monetary policy in Bangladesh: An econometric investigation. Indian Economic Review, 28(1), 85-100.

Khan, R. E. A., \& Hye, Q. M. A. (2013). Financial liberalization and demand for money: A case of Pakistan. The Journal of Developing Areas, 47(2), 175-198.

Kishor, N. K., \& Ssozi, J. (2011). Business cycle synchronization in the proposed East African monetary union: An unobserved component approach. Review of Development Economics, 15(4), 664-675.

Kumar, S. (2011). Financial reforms and Money demand: Evidence from 20 developing countries. Economic System, 35(3), 323-334.

Kumar, S., Webber, D. J., \& Fargher, S. (2013). Money demand stability: A case study of Nigeria. Journal of Policy Modelling, 35(6), 978-991.

Kuteesa, A. (2012). East African regional integration: Challenges in meeting the convergence criteria for monetary union: A survey. International Journal of Economics and Finance, 4(10), 147-160.

Lepetit, L., Rugemintwari, C., \& Strobel, F. (2014). Monetary, financial and fiscal stability in the East African Community: Ready for a monetary union? The World Economy, 38(8), 1179-1204.

Levine, P. (2012). Monetary policy in an uncertain world: probability models and the design of robust monetary rules. Indian Growth and Development Review, 5(1), 70-88.

Mafusire, A., \& Brixiova, Z. (2013). Macroeconomic shock synchronization in the East African Community. Global Economic Journal, 13(2), 261-280.

Miles, W. (2015). The East African monetary union: Is the level of business cycle synchronization sufficient? Wichita State University - W. Frank Barton School of Business.

Mishkin, F. S. (2002). The role of output stabilization in the conduct of monetary policy. International Finance, 5(2), 213-227.

Mkenda, B. K. (2001). Is East Africa an optimum currency area? (Working Papers in Economics, No. 41). School of Economics and Commercial Law, Goteborg University.

Nachega, J. C. (2001). Financial liberalization, money demand and inflation in Uganda (IMF Working paper No. 01/118). Washington. 
Ndirangu, L., \& Nyamongo, E. M. (2015). Financial innovations and their implications for monetary policy in Kenya. Journal of African Economics, 24(Supplement), i48-i71.

Pesaran, H. M., Shin, Y., \& Smith, R. J. (2001). Bounds testing approaches to the analysis of level relationships. Journal of Applied Econometrics, 16(1), 289-326.

Poole, W. (1970). Optimal choice of monetary policy instruments in a simple stochastic macro model. The Quarterly Journal of Economics, 84(2), 192-216.

Rao, B. B., \& Kumar, S. (2009). A panel data approach to the demand for money and the effects of financial reforms in the Asian countries. Economic Modelling, 26(5), 1012-1017.

Rusuhuzwa, T. K., \& Masson, P. R. (2012). Design and implementation of a common currency area in the East African Community (Department of Economics Working Paper No. 451). University of Toronto, Toronto.

Sheikh, K. A., Azam, M. N., Rabby, T. G., Alam, G. M., \& Khan, I. (2011). Monetary union for the development process in the East African community: Business cycle synchronization approach. African Journal of Business Management, 5(17), 7632-7641.

Singh, R., \& Kumar, S. (2012). Application of the alternative techniques to estimate demand for money in developing countries. Journal of Developing Areas, 46(2), 43-63.

UNCTAD. (2014, June). Monetary unions and regional trade in Africa. United Nations Conference on Trade and Development, Trade and Development Broad Fifty-ninth executive session Geneva. Retrieved June 25, 2016, from http://unctad.org/meetings/en/SessionalDocuments/tdbex59d3_en.pdf Weeks, J. (2010). Why monetary policy is irrelevant in Africa South of the Sahara. School of Oriental and African Studies, Center for Development and Policy Research, Development Viewpoint No. 53. Retrieved October 29, 2012, from http://www.soas.ac.uk/cdpr/publications/dv/file59766.pdf 